\title{
Case study of lean manufacturing application in a die casting manufacturing company
}

\begin{abstract}
The case study of lean manufacturing aims to study the application of lean manufacturing in a die casting manufacturing company located in Pulau Penang, Malaysia. This case study describes mainly about the important concepts and applications of lean manufacturing which could gradually help the company in increasing the profit by studying and analyzing their current manufacturing process and company culture. Many approaches of lean manufacturing are studied in this project which includes: 5S housekeeping, Kaizen, and Takt Time. Besides, the lean tools mentioned, quality tool such as the House of Quality is being used as an analysis tool to continuously improve the product quality. In short, the existing lean culture in the company is studied and analyzed, with recommendations written at the end of this paper.
\end{abstract}

Keyword: 5S; Takt time; House of quality; Lean manufacturing 